\title{
A Model to Compare QoL in Turkish Cities
}

\author{
Ebru Çubukçu, İrem Erin
}

\author{
Department of City and Regional Planning, Faculty of Architecture, Dokuz Eylul University, Tınaztepe Kampüsü, \\ Doğuş Caddesi No:209, İzmir 35160, Turkey \\ ebru.cubukcu@deu.edu.tr, irem.erin@deu.edu.tr
}

\begin{abstract}
Quality of life (QOL) is an abstract concept. Like other subjective concepts, it is hard to develop objective measures to understand QOL in specific urban settings. Since there has been a voluminous literature on $\mathrm{QOL}$, researchers focused on parameters to measure $\mathrm{QOL}$. This study aims to review the literature on QOL to extract the indicators of QOL in urban settings. It would put forward a model to collect data to measure and compare QOL in neighborhood units and regional areas. The model could be applied in Turkish cities. The potential and limitations of this model will be discussed.

Keywords: Quality of life; micro / macro scale; neighborhood unit; environment and behavior studies.

eISSN 2398-4279 @ 2018. The Authors. Published for AMER ABRA cE-Bs by e-International Publishing House, Ltd., UK. This is an open access article under the CC BY-NC-ND license (http://creativecommons.org/licenses/bync-nd/4.0/). Peer-review under responsibility of AMER (Association of Malaysian Environment-Behaviour Researchers), ABRA (Association of Behavioural Researchers on Asians) and $c E-B s$ (Centre for EnvironmentBehaviour Studies), Faculty of Architecture, Planning \& Surveying, Universiti Teknologi MARA, Malaysia.

https://doi.org/10.21834/ajqol.v3i11.116
\end{abstract}




\subsection{Introduction}

Quality of life (QOL) which is defined as overall well-being of societies and individuals in general, is an extensive discourse which is subjected to various research in diverse disciplines (El Din et al., 2013, Keles, 2012, Mohit, 2013a). QOL is also explained as "a concept linked to that of social well-being, which is based on the argument that the human condition should be evaluated on a wider range of indicators than just income - whether at the individual level or through national aggregates" (Gregory, 2011). Mohit (2013a) argued that QOL has more than a dozen definitions and listed seven main disciplines (economics/political science, sociology/psychology, health studies, housing, marketing, cities level analysis, urban analysis; three of which are focusing on physical environmental and spatial issues) studying QOL. This study aims to review the literature from an environmental psychology perspective and discuss the parameters related to QOL for different geographies.

\subsection{Literature Review}

QOL is a buzzword for decades and has been studied seriously in developed countries since 1970 s and in developing countries since 1990s. Governments are seeking to improve QOL in their cities as it is considered as the main domain of development and user satisfaction. Moreover, QOL has become a fundamental concept in city marketing and place promotion. Thus, it is subjected to numerous research. In spite of voluminous literature on QOL in environmental studies, two points are still challenging researchers (1) the meaning of QOL (Dülger Türkoğlu et al., 2009, Mohit, 2013a) and, (2) defining the parameters and standards in measuring the QOL (Dülger Türkoğlu et al., 2009, Keles, 2012, Khalil, 2012). This challenge occurs because the phenomenon of QOL is an extensive issue with wide range of indicators and its parameters of measure changes from research to research, city to city, culture to culture and scale to scale. World Health Organization (WHO), as well as Organisation for Economic Co-operation and Development (OECD), developed a common international - cross cultural instrument to measure and compare QOL in countries (Mohit, 2013a). Yet, Mohit (2013b) argued that a uniform index has not been developed for the fourteen states/ regions in Malaysia. Same applies to Turkey, there is no uniform instrument to measure and compare $\mathrm{QOL}$ in different regions, cities and neighborhoods.

This paper aims to review the QOL studies and to develop a model to measure QOL in Turkey.

\subsection{Methodology}

Twenty studies related to "environment and behavior" studies from diverse geographies were reviewed. The studies were from Turkey, USA, India, Argentina, Italy, Tunisia, Egypt, Cyprus, Iran, and Malaysia covering cities of different sizes. The parameters varied from economic, social, political to physical environment. Correspondingly, indicators of physical environment vary in scale from housing to regional. Majority were empirical studies conducted in macro scale environments using subjective data and rely on research based data (rather than 
national databases). The number of indices used to understand $\mathrm{QOL}$ vary from one (Hassine et al. 2014, Lloyd\&Auld, 2003) to more than 50 parameters (Türkoğlu, 2011).

Table 1: Qualifications of selected papers on QOL

\begin{tabular}{|c|c|c|c|c|c|c|}
\hline 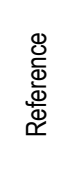 & 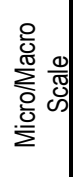 & 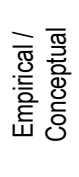 & 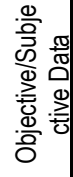 & 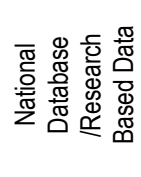 & $\begin{array}{l}\overline{8} \\
\frac{1}{ \pm} \\
\sum\end{array}$ & 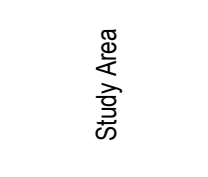 \\
\hline 1 & $\mathrm{Mi}$ & $E$ & $S$ & R.B.D. & Questionnaire & Istanbul/Turkey \\
\hline 2 & $\mathrm{Ma}$ & $E$ & 0 & N.D. & Analytical Model & USA Counties \\
\hline 3 & $\mathrm{Mi}$ & $\mathrm{El}$ & 0 & R.B.D. & $\begin{array}{c}\text { Spatial } \\
\text { Calculations }\end{array}$ & Istanbul/Turkey \\
\hline 4 & $\mathrm{Ma}$ & $E$ & $S$ & R.B.D. & Questionnaire & Guwahati/India \\
\hline 5 & $\mathrm{Ma}$ & $E$ & O\&S & R.B.D. & $\begin{array}{l}\text { Maps, calculations } \\
\text { and questionnaire }\end{array}$ & La Plata/Argentina \\
\hline 6 & $\begin{array}{c}\text { Ma\& } \\
\text { Mi }\end{array}$ & $E$ & $S$ & R.B.D.\&N.D & Interviews & Istanbul/Turkey \\
\hline 7 & $\mathrm{Ma}$ & C & - & - & - & - \\
\hline 8 & $\mathrm{Mi}$ & $E$ & $S$ & R.B.D. & Questionnaire & $\begin{array}{c}\text { Agrigento, } \\
\text { Bologna, Cesena, } \\
\text { Florence, } \\
\text { Grosseto, L'Aquila, } \\
\text { Latina, Matera, } \\
\text { Palermo, Pescara, } \\
\text { and Salerno / Italy }\end{array}$ \\
\hline 10 & $\mathrm{Mi}$ & $E$ & $S$ & R.B.D. & Questionnaire & $\begin{array}{l}\text { Tunis, Sousse, and } \\
\text { Sfax /Tunusia }\end{array}$ \\
\hline 11 & $\mathrm{Mi}$ & C & - & - & - & - \\
\hline 12 & $\mathrm{Ma}$ & C & - & - & - & - \\
\hline 13 & $\mathrm{Ma}$ & C & - & - & - & $\begin{array}{c}\text { AlShohada and } \\
\text { Badr /Egypt }\end{array}$ \\
\hline 14 & $\mathrm{Ma}$ & C & - & - & - & - \\
\hline 15 & $\begin{array}{c}\mathrm{Ma} \& \\
\mathrm{Mi}\end{array}$ & C & - & 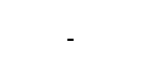 & 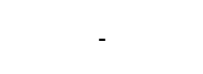 & - \\
\hline 18 & $\mathrm{Mi}$ & E & S & R.B.D.\&N.D & $\begin{array}{l}\text { Face to face } \\
\text { interviews }\end{array}$ & Famagusta/Cyprus \\
\hline 20 & $\mathrm{Ma}$ & C & - & - & - & - \\
\hline 21 & $\mathrm{Mi}$ & $E$ & S & R.B.D. & Questionnaire & $\begin{array}{c}12 \text { counties of } \\
\text { western Virginia }\end{array}$ \\
\hline 22 & Mi & $E$ & $S$ & R.B.D. & Questionnaire & Tehran/Iran \\
\hline 24 & $\begin{array}{c}\mathrm{Ma} \& \\
\mathrm{Mi}\end{array}$ & $E$ & S & R.B.D.\&N.D & $\begin{array}{l}\text { Face to face } \\
\text { interviews }\end{array}$ & Istanbul/Turkey \\
\hline
\end{tabular}




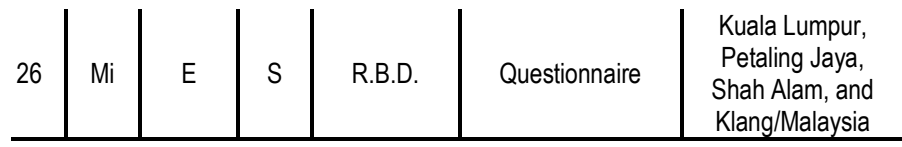

\subsection{Findings and Discussions}

The literature review showed that the parameters of quality of life are diverse. Parameters related to physical environment can be categorized into 8 headings (Table 2). Most of these parameters have been measured subjectively via questionnaires and face to face interviews. Only a few have been based on objective data. For the subjective data; likert scale was used to understand the respondents' satisfaction on various issues such as aesthetics of the built environment, public transport or solid waste disposal system (Fornara et al, 2010; Karim, 2011; Türkoğlu et al., 2011). Objective data were collected via geographic information systems to calculate parameters related to building density, average building age on the street or width of street (Berköz et al., 2009; Bölen et al., 2007).

Table 2: Indicators of QOL

\begin{tabular}{ll}
\hline Reference & Residential \\
\hline 1 & Size of the housing area, closeness of buildings, number of floors \\
3 & Area and width of parcel \\
3,8 & Building density \\
3 & Number of dwelling units in the building \\
$3,10,18,22,26$ & Population density \\
3 & Age of building \\
3 & Average building age on the street \\
3 & Age of the subdivision on the site \\
8 & Building volume \\
21,26 & Upkeep of homes and yards \\
3 & Slope of the parcel \\
3 & Orientation of the parcel \\
3 & Existence of a pleasant view \\
$3,10,22,24$ & Quality of the building \\
$4,6,22,26$ & Conditions of housing \\
7 & Upkeep of heritage and historical remains \\
$1,5,7,8,10,11,24$ & Aesthetics of the built environment \\
7,26 & Housing types \\
7,24 & Public places \\
$6,8,24$ & Macro upkeep and micro upkeep \\
3 & Development process: planned/ unplanned \\
&
\end{tabular}




\begin{tabular}{|c|c|}
\hline 21 & Neighborhood improvement \\
\hline \multirow[t]{2}{*}{22} & Neighborhood attractions \\
\hline & Transport \\
\hline $1,3,11,20$ & Accessibility to city centre \\
\hline 3 & Distance to district centre \\
\hline 3 & Distance to nearest main street \\
\hline 3 & Distance to airport \\
\hline 3 & Distance to seaside \\
\hline 3 & Distance to nearest kindergarten \\
\hline $\begin{array}{l}1,3,4,5,6,7,10,15,20,22, \\
24\end{array}$ & Quality and accessibility of public transport and public transport stops \\
\hline $1,4,7,10,18$ & Traffic density \\
\hline $1,5,7,18$ & Traffic roads \\
\hline 1,7 & Safety against traffic accidents \\
\hline 1,3 & Ratio of parking area \\
\hline 8 & External connections \\
\hline 7,8 & Internal functionality \\
\hline 24 & Length of travel in time and distance \\
\hline 1,22 & Accessibility to work \\
\hline 1 & Accessibility to places of entertainment \\
\hline $1,15,22$ & Accessibility to shopping centre \\
\hline 1 & Accessibility to the market where daily needs are obtained \\
\hline 22 & Accessibility to gas station \\
\hline $1,3,7,11,21,22,24$ & Accessibility to elementary schools \\
\hline $1,7,11,21,22,24$ & Accessibility to high schools \\
\hline $1,22,24$ & Accessibility to parking areas \\
\hline 1 & Accessibility to walking areas \\
\hline $1,11,22$ & Accessibility to sports centres \\
\hline 1,22 & Accessibility to local clinics \\
\hline $1,7,11,21,22$ & Accessibility to hospital \\
\hline 20 & Accessibility to housing area \\
\hline $1,5,7,10,22,24$ & Quality of pedestrian paths and walkability \\
\hline $3,7,10,18,24$ & Status of the street \\
\hline 3 & Type of pavement \\
\hline 3 & Width of street \\
\hline 3 & Width of pavement \\
\hline 3 & Slope of the street \\
\hline & Safety \\
\hline
\end{tabular}




\begin{tabular}{|c|c|}
\hline 21 & Street lighting in the neighborhood \\
\hline $1,5,8,10,15,18,20,24,26$ & Perception of general safety in the housing area and in the neighborhood \\
\hline \multirow[t]{2}{*}{$11,20,22,24$} & Actual and perceived level of crime \\
\hline & Environment \\
\hline $4,20,22$ & Level of environmental pollution in the city \\
\hline $4,5,11$ & Sanitation \\
\hline $1,3,4,5,7,11,15$ & Clean water \\
\hline $4,10,11$ & Drainage system \\
\hline 4 & Water supply duration \\
\hline 4,5 & Source of water \\
\hline $3,5,10,22$ & Sewerage system \\
\hline $4,7,10,11,22,24$ & Solid waste disposal system \\
\hline $5,15,22,24$ & Hazardous waste \\
\hline $4,5,7,10,15,24$ & Air quality \\
\hline $\begin{array}{l}4,5,10,11,15,18,22,24 \\
26\end{array}$ & Noise pollution \\
\hline 10,11 & Odors \\
\hline $1,3,5$ & Natural gas \\
\hline $1,5,11$ & Access to telephone and cable television \\
\hline $1,5,11$ & Access to electricity \\
\hline 7 & Minimization of energy demand \\
\hline 20 & Climate \\
\hline 24 & Loss of natural spaces \\
\hline \multirow[t]{2}{*}{1} & Safety against natural disasters (earthquake, flood, etc.) \\
\hline & Socio-Cultural \\
\hline $1,4,10,20,24$ & Presence of / satisfaction with shopping facilities \\
\hline $1,8,15,20$ & Presence of / satisfaction with socio-cultural activities and resources \\
\hline \multirow[t]{2}{*}{10} & $\begin{array}{l}\text { Presence of / satisfaction with leisure facilities (cafe's, restaurants, cultural } \\
\text { places) }\end{array}$ \\
\hline & Recreational \\
\hline 3,4 & Presence of / satisfaction with open space \\
\hline 3 & Presence of / satisfaction with livable space \\
\hline $1,11,21$ & Presence of / satisfaction with landscape and scenery \\
\hline $3,4,15,18,20$ & Presence of / satisfaction with recreation area \\
\hline $\begin{array}{l}1,3,4,5,7,10,15,18,22 \\
24\end{array}$ & Presence of / satisfaction with parks and green areas \\
\hline $1,6,15,18$ & Presence of / satisfaction with walking areas \\
\hline 1 & Presence of / satisfaction with relaxation areas \\
\hline $1,3,8,10$ & Presence of / satisfaction with sport fields and sport centres \\
\hline $1,11,15,21,24$ & Presence of / satisfaction with children's playgrounds and outdoor play space \\
\hline 1,5 & Presence of / satisfaction with night lighting \\
\hline & \\
\hline
\end{tabular}




\section{Educational}

$1,5,8,15,20,22$

Quality of educational facilities

\begin{tabular}{ll}
\hline & Health \\
\hline $1,4,5,24$ & Quality of health facilities \\
$20,22,24$ & Health care/public health and sanitation \\
8 & Social care services \\
15 & Number of visits to doctors \\
\hline
\end{tabular}

Moreover databases used by Organisation for Economic Co-operation and Development's (OECD), World Health Organization's (WHO) and Turkish Statistical Institution's (TUIK) were analyzed as well.

OECD'S index listed eleven dimensions in which water quality and air pollution are the only indices related to physical environment (OECD, n.d.).

- Housing

- Income

- Jobs

- Community

- Education

- Environment

- Civic Engagement

- Health

- Life Satisfaction

- Safety

- Work-Life Balance

A subgroup of WHO, WHOOQOL (World Health Organization Quality of Life) has developed a measure to be applicable cross-culturally. This measure included six domains:

- Physical

- Psychological

- Level of Independence

- Social Relationships

- Environment

- Spirituality/Religion/Personal Beliefs

Dimension related to physical environment included the following questions (WHOQOL, 2012):

- How important to you is / are

- your home environment?

- it being able to get adequate health care?

- it being able to get adequate social help?

- chances for getting new information or knowledge?

- relaxation/leisure?

- your environment? (e.g. pollution, climate, noise, attractiveness)? 
- adequate transport in your everyday life?

TUIK, a Turkish governmental institution, have been collecting statistical data on life satisfaction in all cities of Turkey since 2003. According to the research, which is conducted in 2014, life satisfaction is measured in six dimensions:

- Life Standards of Household

- Individual Happiness and Self-satisfaction

- Satisfaction with Public Services

- Expectation, Personal Development and Hope

- Values

- Perspective to European Union

Among these dimensions, only satisfaction with public services seems to be related to physical environment. This dimension searches satisfaction with health facilities, satisfaction with educational facilities, safety in and around schools, accessibility to schools, safety of housing environment, satisfaction with transportation services, satisfaction with services of municipalities and special provincial administration (disposal of waste, water supply, street lighting, cleaning services, sewage system service, public transportation services, upkeep of streets, amount of green spaces, sport facilities and air pollution) (TUIK, 2015).

\subsection{Conclusion}

QOL has been studied by various disciplines. Despite a voluminous literature covering QOL issues in diverse geographies (from local to national scales), there is still little knowledge on indicators of QOL. How each indicator is measured in different scale environments (region/state, city, and neighborhood) could vary as well. This study reviews the indicators used in QOL research (empirical or conceptual) in the literature of environmental psychology and QOL parameters collected in national and local databases (OECD, WHO, and TUIK). After eliminating the parameters unrelated to local conditions in Turkey, results showed that there are various indices to measure $\mathrm{QOL}$, and these measurements are made both by subjective data and objective data. Furthermore, OECD, WHO and TUIK have less spatial indicators compared to those studied in Environmental Psychology Research.

The literature review showed that the parameters discussed in empirical studies were parallel, and they mostly fall into the same categories. Yet, OECD, WHO and TUIK indices lack physical environmental content. Although, TUIK seems to have more indices related to urban data, it is limited to satisfaction with the services of municipalities.

This study highlights that, QOL indices related to urban environments at the national level (macro scale) involves information on population density, traffic safety, air quality, and leisure facilities. In contrast, at the local level (micro scale) parameters which are specific to that area should be well observed and taken into consideration. Moreover some parameters (such as race relations or the amount of rodents) can be important indices in some geographies (eg. United States and Tunisian cities) but not in others (Turkish cities). This study aims to discuss the new directions for future research. First, the sample size (the literature) could be extended and studies to be reviewed should be selected via a systematical approach. More 
research are on call to develop a uniform set of parameters and their measures in different scales in Turkey to compare the QOL in different regions, cities and neighborhoods. Such comparisons would lead the development of policy guidelines in national and local levels. Finally, this study aims to pave the way to develop a model to measure QOL in Turkish cities. In this model there are eight dimensions, which are residential, transport, safety, environment, socio-cultural, recreational, educational and health related. Residential, transport and environment dimensions have the most parameters. Public transport, accessibility to educational and health facilities, aesthetics of the built environment, safety and security, clean water, air quality, educational facilities, solid waste disposal system, noise pollution, parks and green areas are the most mentioned parameters by researchers. Global and local institutions should collaborate with researchers to identify general parameters and collect data on spatial indices of QOL.

* A different version of this manuscript is presented in AQoL2015/zmir, Turkey, 09-13 December 2016 with the title of "Indicators of Quality of Life to Compare Neighborhood Units and Regional Areas: A model to collect data at micro and macro scale urban issues in Izmir, Turkey"

\section{References}

Berkoz, L., Turk, Ş. Ş., \& Kellekci, Ö. L. (2009). Environmental quality and user satisfaction in mass housing areas: the case of Istanbul.

Blomquist, G. C., Berger, M. C., \& Hoehn, J. P. (1988). New estimates of quality of life in urban areas. The American Economic Review, 89-107.

Bolen, F., Türkoğlu, H., Ergun, N., Yirmibeşoğlu, F., Terzi, F., Kaya, S., \& Kundak, S. (2007, August). Quality of residential environment in a city facing unsustainable growth problems: Istanbul. In Joint Congress of the European Regional Science Association and the Association de Science Régionale de Langue Française, Paris, August/September.

Das, D. (2008). Urban quality of life: A case study of Guwahati. Social Indicators Research, 88(2), 297-310.

Discoli, C., Martini, I., San Juan, G., Barbero, D., Dicroce, L., Ferreyro, C., \& Esparza, J. (2014). Methodology aimed at evaluating urban life quality levels. Sustainable Cities and Society, 10, 140-148.

Dülger Türkoğlu, H., Bölen, F., Baran, P. K., \& Marans, R. W. (2009). İstanbul'da yaşam kalitesinin ölçülmesi. ITÜDERGisila, 7(2).

El Din, H. S., Shalaby, A., Farouh, H. E., \& Elariane, S. A. (2013). Principles of urban quality of life for a neighborhood. HBRC Journal, 9(1), 86-92.

Fornara, F., Bonaiuto, M., \& Bonnes, M. (2010). Cross-validation of abbreviated perceived residential environment quality (PREQ) and neighborhood attachment (NA) indicators. Environment and Behavior, 42(2), 171-196.

Gregory, D., Johnston, R., Pratt, G., Watts, M., \& Whatmore, S. (Eds.). (2011). The dictionary of human geography. John Wiley \& Sons.

Hassine, K., Marcouyeux, A., Annabi-Attia, T., \& Fleury-Bahi, G. (2014). Measuring Quality of Life in the 
Neighborhood: The Cases of Air-Polluted Cities in Tunisia. Social Indicators Research, 119(3), 1603-1612.

Karim, H. A. (2012). Low Cost Housing Environment: Compromising Quality of Life?. Procedia-Social and Behavioral Sciences, 35, 44-53.

Keles, R. (2012). The Quality of Life and the Environment. Procedia-Social and Behavioral Sciences, 35, 23-32.

Khalil, H. A. E. E. (2012). Enhancing quality of life through strategic urban planning. Sustainable Cities and Society, 5, 77-86.

Lloyd, K., \& Auld, C. (2003). Leisure, public space and quality of life in the urban environment. Urban policy and research, 21(4), 339-356.

Marans, R. W. (2012). Quality of urban life studies: An overview and implications for environment-behaviour research. Procedia-Social and Behavioral Sciences, 35, 9-22.

Mohit, M. A. (2013a). Quality of Life in Natural and Built Environment-An Introductory Analysis. Procedia-Social and Behavioral Sciences, 101, 33-43.

Mohit, M. A. (2013b). Objective analysis of variation in the regional quality of life in Malaysia and its policy implications. Procedia-Social and Behavioral Sciences, 101, 454-464.

Oktay, D., Rüstemli, A., \& Marans, R. W. (2009). Neighborhood satisfaction, sense of community, and attachment: Initial findings from Famagusta quality of urban life study. ITU A/Z Journal, 6(1), 6-20.

Organisation for Economic Co-operation and Development (OECD). How's Life. (n.d.). Retrieved from http://www.oecdbetterlifeindex.org/

Rogerson, R. J. (1999). Quality of life and city competitiveness. Urban studies,36(5-6), 969-985.

Sirgy, M. J., \& Cornwell, T. (2002). How neighborhood features affect quality of life. Social indicators research, 59(1), 79-114.

Soleimani, M., Tavallaei, S., Mansuorian, H., \& Barati, Z. (2014). The Assessment of Quality of Life in Transitional Neighborhoods. Social Indicators Research, 119(3), 1589-1602.

Türkiye İstatistik Kurumu (TUIK). (2015). Yaşam Memnuniyeti Araştırması, 2014. Türkiye İstatistik Kurumu Matbaası, Ankara.

Türkoğlu, H., Bölen, F., Baran, P. K., \& Terzi, F. (2011). Measuring quality of urban life in Istanbul. In Investigating quality of urban life (pp. 209-231). Springer Netherlands.

World Health Organization Quality of Life Group (WHOQOL). (2012). WHOQOL-SRPB Field-Test Instrument. World Health Organization, Geneva.

Zainal, N. R., Kaur, G., Ahmad, N. A., \& Khalili, J. M. (2012). Housing conditions and quality of life of the urban poor in Malaysia. Procedia-Social and Behavioral Sciences, 50, 827-838. 